\title{
The impact of students' attitude and subjective norm on the behavioural intention to use services of banking system
}

\author{
Khaled Mohammed Alqasa \\ Universiti Utara Malaysia, \\ 06010 Sintok, Kedah, Malaysia \\ E-mail: khaled20767@yahoo.com
}

\section{Filzah Mohd Isa}

School of Business Management, College of Business, Universiti Utara Malaysia, 06010 Sintok, Kedah, Malaysia

Fax: 604-9285761

E-mail: filzah@uum.edu.my

\section{Siti Norezam Othman}

Universiti Utara Malaysia, 06010 Sintok, Kedah, Malaysia E-mail: norezam@uum.edu.my E-mail: snorezam@gmail.com

\author{
Ali Hussein Saleh Zolait* \\ Department of Information Systems, \\ College of Information Technology, \\ University of Bahrain, \\ P.O. Box 32038, Sakhir - Bahrain \\ Fax: (973) 1744-9119 \\ E-mail: azolait@uob.uob.edu.bh \\ E-mail: alizolait@gmail.com \\ *Corresponding author
}

\begin{abstract}
This study examines the ability and application of the theory of reasoned action (TRA) in explaining the use of banking system in Yemen. It investigates the impact of two theoretical variables (attitude and subjective norms), using a sample consists of university students, on individuals' intention to use banking services. The results of the study revealed a strong predictive power of the theory of reasoned action model to explain university students' behavioural intention to use banking services. Statistically, the finding demonstrated that there are significant and positive relationships between students' attitude, subjective norm as predictor variables on the criterion variable of behavioural intention to use banking services in the context of
\end{abstract}


Yemen. This study adds to the literature by showing non-financial variables such as attitude and subjective norm, which are important in understanding the behavioural intentions toward using banking services. It also provides some theoretical and practical implication. This study is one of the few studies that used theory of reasoned action in the context of Yemen. Furthermore, it has proven its effectiveness in predicting the behavioural intention of students towards using banking services. In addition, the finding will help to design strategies to attract more customers to use the banking system.

Keywords: theory of reasoned action; TRA; behavioural intention; adoption of financial systems; attitude; subjective norms.

Reference to this paper should be made as follows: Alqasa, K.M., Mohd Isa, F., Othman, S.N. and Zolait, A.H.S. (2014) 'The impact of students' attitude and subjective norm on the behavioural intention to use services of banking system', Int. J. Business Information Systems, Vol. 15, No. 1, pp.105-122.

Biographical notes: Khaled Mohammed Alqasa is a Lecturer in Marketing and Strategic Management in University of Aden, Yemen. He obtained his Bachelor, 2001 and Master's in Business Administration from University of Aden, 2005. He obtained his $\mathrm{PhD}$ in Business Administration from University Utara Malaysia (Northern University of Malaysia). His teaching interest is integrated marketing communications.

Filzah Mohd Isa is a Senior Sales and Marketing Lecturer in Universiti Utara Malaysia (Northern University of Malaysia). She was a BBA graduate from University of South-western Louisiana, USA (1987), and MBA graduate from Northrop University, Los Angeles, USA (1989). She obtained her Doctoral of Business Administration from University Sains Malaysia in 2007. She has a local and international working experience in marketing. Her interests are in marketing research, training programs and postgraduate students' supervision.

Siti Norezam Othman is a Senior Lecturer at College of Business, University Utara Malaysia. She has 15 years experience in teaching subjects such as operations management and technology management. Her research interests cover topics in supply chain management, technology transfer, technology assessment, and operations management. She is the Managing Editor for Journal of Technology and Operations Management. She affiliates with International Association of Management of Technology.

Ali Hussein Saleh Zolait is an Assistant Professor of MIS at the College of Information Technology, University of Bahrain - Kingdom of Bahrain. He is teaching subjects such as system analysis and design, management of information system, IT project management. His interest is in IS research such as adoption of technology and system, IS performance, e-banking, diffusion of innovation, security and e-commerce. He has several articles published in the leading International Journal of Marketing and Information Systems. He is also the Editor-in-Chief of International Journal of Technology Diffusion (IJTD). 


\section{Introduction}

Banking services are considered as the cornerstone of recent economies. These services constitute a large and growing sector in most economies throughout the world, in developed or developing countries alike. All sectors of the business activities nowadays are basically dependent on their access to banking services (Khaledi et al., 2012). In addition, banks are mobilising savings from the surplus sectors (depositors) then transferring this money to their clients (deficit sectors) in the form of loans to activate the investment, such that all savings are injected as investments (Gilaninia et al., 2011).

The Yemeni banking systems is similar to other banking systems in many developing countries, particularly as it has been reported to have many problems affecting many aspects of economic life (Swidi and Mahmood, 2011). One of the most pressing challenges facing banks currently is the lack of depositors and customers, and the majority of the population hesitates in trusting banks with their money (McLeod and Pippin, 2012). Challenges of this type influence the ability of the banking system to finance investments in the country. In addition, the Yemeni economy is described as a cash economy, where most of the people deal with cash in many aspects of trading and commercial transactions, even for the most durable purchases (Al-Mushrqui, 2009). Moreover, the maximum checks annually circulated are between 500,000 to 600,000 . These facts have been reported by a study carried out by the Malaysian company, SIRIM Berhad 2010 (Swidi and Mahmood, 2011).

This study attempts to examine the university students' behavioural intention to use banking system. Researchers adapted the theory of reasoned action (TRA), which is one of the widely theories that used to understand the consumer's decision. Also, studying and analysing factors such as, consumers' attitude toward the behaviour in question. Moreover, studying subjective norm, and its effects on the consumer's intention towards the actual behavioural (e.g., Ajzen and Fishbein, 1980; Sadeghi and Farokhian 2011; Al-Maghrabi and Dennis, 2012). The researchers considered the university students the most important segment of consumers for the current study because it represent people who are in the age ranging between 20 to 35 years. The demographic segment is the largest segment of bank customers in most societies as reported by Rugimbana (2007). For instance, it is considered a sizeable number of the Yemeni population, which was about of 22.2 million persons in 2007 (Library of Congress, 2008).

\section{Literature review}

Understanding what determinants influence individuals to use information systems (IS) would help managers improve the process of facilitating system implementation (Wang and Butler, 2006). Although describing a human behaviour is usually confusing and at the same time it is an important subject, many researchers tend to use psychological determinants to understand the behaviour of potential adopters (Fishbein and Ajzen, 1975). TRA was created by Fishbein and Ajzen (1975) and has been extensively deployed to examine human behaviour in the social psychological disciplines (Tan et al., 2012). The theory proposed attitudes, subjective norms, intentions, and behaviours as the main constructs in the TRA. The theory investigates how attitudes and subjective norm determine the volitional behaviour. Many studies adopts Ajzen and Fishbein's theory and 
applied it to a variety of fields, such as donation, occupational tendency, bone marrow, learning motivation, as well as consumer behaviour (Weber et al., 2007; Lin et al., 2011; Bagozzi et al., 2007; Addison and Chou, 2003; Amin and Chong, 2011). In addition, it is widely applied to fields such as management, finance, and marketing. In conclusion, the theory of TRA lean to diversify and theory application unquestionable and justified, because it has been widely applied to the banking services fields and shows a strong predictor for behavioural intention and actual behaviour (Yousafzai et al., 2010; Hernandez and Mazzon, 2007; Lymperopoulos and Chaniotakis, 2005; Page and Luding, 2003). According to the TRA, the determinant of a person's behaviour is his or her intention to perform or not to perform the particular action (Hostler et al., 2011). The theory assumes that a person's intention is a function of the two basic determinants; one of them personal in nature, the other reflecting social influence as shown in Figure 1. The first determinant is the attitude toward the behaviour, which explains the individual's positive or negative evaluation of performing the behaviour. Attitude means that individuals with a highly positive tendency to do something would be more likely to respond favourably, whereas individuals with a highly negative disposition would be more likely to respond negatively (Ajzen et al., 2004). In addition, an individual's attitude is determined by individuals' beliefs about an object or person as reported by Lee et al. (2011). The second determinant is the subjective norm that represents the individual's perception of the social pressure put on him by people who are important to him to perform or not perform a specific behaviour (Shin, 2009).

Figure 1 Theory of reasoned action

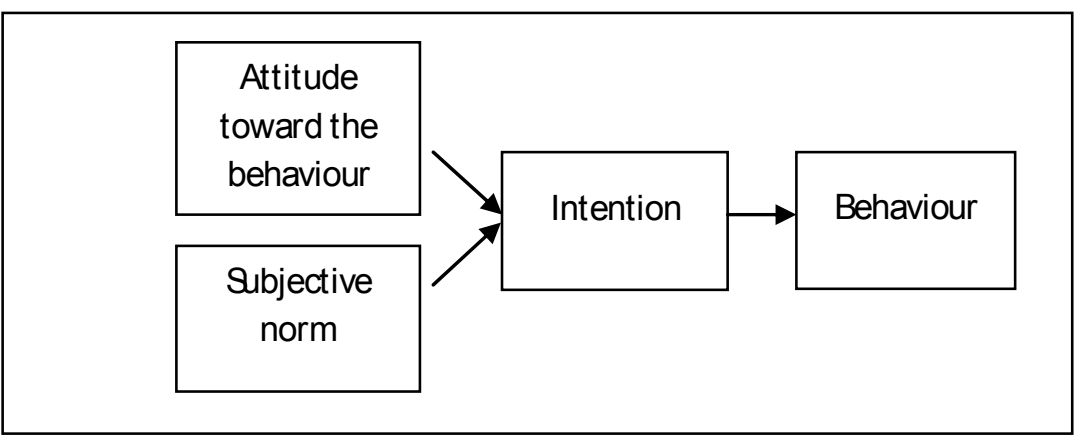

Source: Adapted from Ajzen and Fishbein (1980)

There are many studies have been used TRA and show the predictive power of the theory on actual behaviour in different contexts (Wang and Butler, 2006). All these kinds of individual behaviour can account for the theory of reasoned action. It is clear that consumer's intention to perform an actual behaviour is jointly determined by the two factors; namely, attitude toward the actual behaviour and subjective norm. In line with this, many studies have found a positive relationship between consumer's attitude and behavioural intention, (Hyllegard et al., 2009; Kim, 2008; Prendergast et al., 2008; Tarkiainen and Sundqvist, 2005). In this context, attitude actually related to the behavioural intention as individuals form intentions to perform behaviours toward which they are positively oriented. For instance, this research relates to the attitude toward using banking services, whereby if people have a positive attitude toward financial services that banks offer, they are more likely to have the intention to use these services. Similarly, the 
second predictor of consumer's intention is the subjective norm, which is a function of beliefs about the expectation of the important referent and his or her motivation of complying with these referents (Fishbein and Ajzen, 1980). According to Fishbein and Ajzen (1980), subjective norm is the social pressure from others who are important to an individual on whether or not to engage in a certain behaviour. The rationale for the effect of $\mathrm{SN}$ is that a person may choose to engage certain behaviour, even though it is not a favourable one at first. If their important referents think they should, they will comply with the particular behavior (Tan et al., 2012). Several studies have shown a positive relationship between subjective norm and consumer intention (Al Muala et al., 2012; Kim, 2008; Prendergast et al., 2008; Tan et al., 2012). In the framework of this study, the researchers investigated these antecedents to examine university students' intention to use banking services in the context of Yemen.

\section{The banking system and economic growth}

The importance of banking systems for the economic is undeniable because economic health nowadays depends more than ever, on the soundness of the banking system (Bayraktar and Wang 2008). Although banks themselves create no new wealth, their activities such as, lending, savings and related activities facilitate the process of exchange, production, and consumption of wealth; hence, they have become very effective partners in the process of economic development (King and Levine, 1992). In this context, using banks is an essential part in the utilisation of the resources of the country in the right direction. Banks are mobilising savings from the surplus sector (depositor) then transferring this money to their clients (deficit sector) in the form of loans to activate the investment, such that all savings are injected as investments (Rosly, 2005). If people do not interact and deal with banks, a great portion of the economic capital would remain idle (George, 2002). Furthermore, banks and financial institutions in the developed countries, which are advanced economically, represent the most important sector (Fadare, 2010). They are depending on banks in leading progress and economic transfer (Yemen Times, 2008).

In Yemen, there is a growing governmental interest in the banking sector due to its important role in leading economic changes and its significant role in supporting the Yemeni economy (CBY Annual Report, 2010). Lack of banking system usage is evident by the estimation that only around 660,000 out of $22,000,000$ million Yemenis use banking systems, constituting a mere 3\%, (Al-Mushrqui, 2009). This calls for a serious study of this sector and the diagnosis of its environmental factors. It has become increasingly and necessary to identify the factors that determine the basis upon why university students do not use banking systems as a tool to facilitate their financial transaction needs. Therefore, this study aims to investigate the influence of students' attitude and subjective norm on behavioural intention toward using banking systems in the context of Yemen.

\subsection{Overview on Yemeni banking system}

Domestic banking system in Yemen has a relatively recent history. In fact, there was no commercial bank until 1970. In 1971, the Central Bank of Yemen (CBY) was established 
as an independent body, created by law to carry out all the functions of a normal central bank. The CBY supreme objective is to lead the monetary policy of the country such as monitor price stability and sustainable economic growth, keep inflation under control, and encourage investment (http://www.centralbank.gov.ye). The Central Bank of Yemen re-shaped in May 1990 by merger of the two banks when the South and North Yemen were re-united.

The bank operates similar to other central banks in attempting to control inflation, stabilise the nation's currency, and encourage foreign investment and growth. One example of the changes caused by the Bank was in July 1996, when it eliminated multiple exchange rates and instead floated the Riyal (http://www.centralbank.gov.ye).

In the 1990s, the banking system in Yemen suffered from extremely low capitalisation rates, and insufficient loan provision because of the shortage of deposits. The banking sector did not have the ability to finance investment (World Bank Group, 2010). In 1997, the World Bank sponsored a financial sector reform programme. As a result, the Yemeni authorities to address some problems related to the banking system (Swidi and Mahmood, 2011) carried out reform efforts. A bank reform law was passed in 1998 to update, strengthen, and regulate the financial industry in Yemen. By 2000, the CBY had circulated strict regulations pertaining to credit risk management, liquidity, insider lending, foreign exchange exposure, financial leasing, and external auditors (Al-Mushrqui, 2009).

The banking system in Yemen is relatively new, small, underdeveloped, and dominated by the government. Bank regulation is insufficient and large business families, who establish financial institutions to serve their own business needs, own most commercial banks. Therefore, they are not willing to finance outside small circles due to the legal inability to collect on overdue debts (Yemen Times, 2008). Consequently, there is a great risk of loan defaulting and at the same time, there is a shortage of deposits and the population is still cautious about putting their money in the banks. In line with this and according to the Mayor of the Central Bank of Yemen, Yemenis prefer to keep their money in their homes instead of dealing with banks. He further confirmed that there are only 600,000 bank accounts, which only represented about $2.7 \%$ of the Yemeni population. Moreover, the maximum checks annually circulated are ranging from 500,000 to 600,000 . These facts have been reported by a study carried out by the Malaysian company, SIRIM Berhad 2010 (Swidi and Mahmood, 2011). As a result, many financial transactions happen outside the commercial banks (Al-Mushrqui, 2009).

\section{Methodology}

Eight hundred and fifty questionnaires were distributed in seven public universities in the Republic of Yemen. Out of 850 questionnaires, only 598 forms were useable for analysis. Hence, the usable response rate is $70.4 \%$, which considered acceptable and larger than what is proposed by Krejcie and Morgan (1970) as reported by Sekaran (2003). The questionnaire consists of two sections:

1 demographic variables ( 9 items)

2 students attitude (4 items), subjective norm (4 items), and behavioural intention (6 items). 
The first section is to gather information about the sample's personal. The second section is to ask the respondents to indicate on a five-point Likert-type scale begin from (1) 'strongly disagree' to (5) 'strongly agree'.

\subsection{Research questions and objectives}

According to the review of literature pertaining to the TRA and previous researches related to banking systems, it is clear that consumer's intention to perform an actual behaviour is jointly determined by two factors; namely, attitude toward the actual behaviour and subjective norm. In line with this, many studies have found a positive relationship between consumer's attitude and behavioural intention, (Hyllegard et al., 2009; Kim, 2008; Lee et al., 2011; Leonard, 2012; Prendergast et al., 2008; Tarkiainen and Sundqvist, 2005). In this context, attitude actually relates to the behavioural intention as individuals form intentions to perform behaviours toward which they are positively oriented. For instance, this research relates to the attitude toward using banking systems, whereby if people have a positive attitude toward financial systems and services that banks offer, the quality in delivering these services as well as banking legal framework that is supposed to protect their deposits, they are more likely to have the intention to use these services. Hence, the proposed hypotheses regarding students' attitude construct are shown in Section 4.2. Based on the literature, the purpose of this study is to test the applicability of reasoned action theory (TRA) in the context of banking systems in Yemen. Therefore, the researchers suggested the following questions:

1 What is the relationship between students' attitude and students' behavioural intention to use bank systems?

2 What is the relationship between subjective norm and students' behavioural intention to use bank systems?

The main goals of this research are to investigate the determinant factors that influence university students to use the services provided by banking system and how these services have been perceived from the viewpoint of the university students in the marketplace. In addition, the researchers attempted to understand the students' subjective norm and attitudes toward services that banks offer in Yemen. In this context, the researchers aim is to achieve the following objectives:

1 To identify the relationship between students' attitude and students' behavioural intention to use bank systems.

2 To examine the relationship between students' subjective norm and students' behavioural intention to use bank systems.

\subsection{Model and research hypotheses}

\subsubsection{Attitude among TRA}

Ajzen and Fishbein (1980) propose that individuals form beliefs about an object by connecting it with various characteristics, attributes and qualities. Due to these beliefs, they possess favorable or unfavouable attitudes toward that object based on whether they connect that object with positive or negative characteristics (Abadi and Gharibpoor, 
2012). These beliefs may be achieved by direct observation, acquiring information from outside sources, or resulted through an inference process. Some beliefs remain, others do not. The challenge is when one attempts to change a perceived attitude (Doll and Ajzen, 1992). Further argument also done by Ajzen and Fishbein (1980) saying that individual attitude toward a specific behaviour is influenced by a set of belief about carrying out the behaviour, As well as the consequences of the behaviour. This argument shows the relation between attitude and subjective norm to behavioural intention is sensitive. Apparently a bit variations of the behaviour under examination can have significant effects upon whether the attitude or subjective norm is more influential (McKemey and Rehman, 2003). The researchers tended to believe that attitudes are a disposition to respond favourably or unfavourably to a behaviour. The favourable or unfavourable response arises from an assessment of the consequence of using banking systems in the context of Yemen. The assessment is influenced by other factors such as the quality and level of banking services provided. These beliefs may yield in changing the university students' behavioural intention to use financial services provided by banking system in Yemen.

\subsubsection{Subjective norm among TRA}

Subjective norm is a function of beliefs namely, the person's beliefs that most people who really matter to him think that he either should or should not perform the behaviour in question. In other words, an individual who believes that most referent with whom he is motivated to comply thinks he should perform the behaviour, will perceive social pressure to do so (Hernandez and Mazzon, 2007). This proposes that an individual will feel social pressure to carry out a behaviour if he is motivated to comply with groups individuals or believes that the behaviour will be approved by significant others. Ajzen and Fishbein (1980) reported that for many practical reasons an identification of the attitude, subjective norm and their relative importance may be adequate to form behavioural intention. However, for a more understanding of behavioural intentions, it is essential to examine why individuals hold certain attitudes and subjective norms, which involve the identification of the behavioural and normative beliefs. That is why the current study uses students' subjective norms to find out the influence of these norms on their behavioural intention to use banking systems.

According to the current study, subjective norm is the level of pressure placed on Yemeni university student by significant people in his or her life, which desire the usage or non-usage of banking systems and their motivation to comply with their views and wishes. If the students believe that their significant others hold favourable attitudes towards using banking system, or if they think that using banking systems would be viewed favourably by significant others, such is such as classmate, friends, parents, peer group etc, they are more likely to carry out that behaviour. In this context, the researchers assume that the choices people make are influenced by their beliefs about how significant others will view their decisions to engage, or not engage, in particular activities.

As mentioned in the literature review, TRA has been used by many studies, and it has been proven as a strong predictor to a behavioural intention, even across different environments and locations (Yousafzai et al., 2010). A large number of studies found strong support for TRA usage (Alajmi, 2010; Sadeghi and Farokhian, 2011; Tsai et al., 2010). 
Most of the previous studies supported and used TRA to understand the customer's behavioural intention in different industries (Aleassa et al., 2011; Southey; 2011; Tsai et al., 2010). The findings of the majority of these studies have proven that TRA is a strong model in predicting consumers' behavioural intention. Hence, TRA is a suitable theory that researcher can use to predict university students' behavioural intention to use banking systems in context of Yemen. Therefore, the study proposes the following hypotheses:

H1 'There is a positive relationship between students' attitude and students' behavioural intention to use bank systems"

$\mathrm{H} 2$ "There is a positive relationship between subjective norm and students' behavioural intention to use bank systems."

Figure 2 demonstrate the current study research model.

Figure 2 Research model

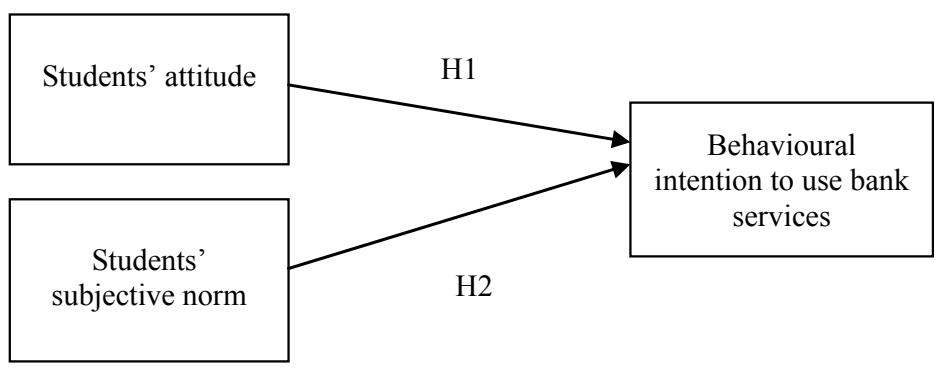

\section{Data and analysis of results}

\subsection{Demographic profile}

It is found that the majority of the respondents are males $470(78.6 \%)$, from the 598, while the female's respondents reported $128(21.4 \%)$. Half of the respondents are between 20 and 30 years old representing (56\%) while $(25.8 \%)$ of the respondents comes from the 31 to 40 age group, the third age group was 41 years old and above which represent $(11.5 \%)$, finally the smallest number of the respondents was under 20 age group with percentage $(6.7 \%)$ of the respondents. Regarding their universities, 155 respondents were from University of Sana'a with (25.9), while University of Aden 112 with (18.7\%), following by Ibb University, al Hudaydah and Ta'az University they were so close from each other obtaining $79(13.2 \%), 78(13 \%)$ and $77(12,9 \%)$ respondents respectively, lastly was Thmar University covered 24 respondents (4\%). Respondents were also asked about their level of education, the majority of the respondents 496 hold a bachelor degree $(82.9 \%)$ whereas the other $102(17.1 \%)$ hold a master's degree. The respondents have varied incomes. The large number of them $234(39.1 \%)$ has monthly earning which is ranging from 80,001 to $100,000 \mathrm{YR}$. There are $139(23.2 \%)$ who they earn a monthly income of YR 60,001 to 80,000. There are 89 (14.9\%) who get more than YR 100,001, following by $77(12.9 \%)$ who get income ranging from YR 40,001 to 60,000 a month. There are $30(5 \%)$ of the respondent earn YR 20,001 to 40,000. Lastly, the smallest 
number of the respondents 29 (4.8\%) earned less than 20,000 YR a month. Finally, the respondents have been asked whether they are bank customers or non-bank customer, it was appeared that at the time of carrying out this study most of them are non-bank customers 567 (94.8\%) compared with only 31 (5.2\%) who are bank customers. Table 1 provides more details.

Table 1 Demographic profiles of the respondents

\begin{tabular}{|c|c|c|}
\hline Profile & Frequency & Percentage \\
\hline \multicolumn{3}{|l|}{ Gender } \\
\hline Male & 470 & 78.6 \\
\hline Female & 128 & 21.4 \\
\hline \multicolumn{3}{|l|}{ Age } \\
\hline Under 20 years & 40 & 6.7 \\
\hline 20 to 30 years & 335 & 56 \\
\hline 31 to 40 years & 154 & 25.8 \\
\hline 41 and above & 69 & 11.5 \\
\hline \multicolumn{3}{|l|}{ University } \\
\hline Sana'a & 155 & 25.9 \\
\hline Aden & 112 & 18.7 \\
\hline Hadramout & 73 & 122 \\
\hline Ta'az & 77 & 12.9 \\
\hline Al Hudaydah & 78 & 13.0 \\
\hline $\mathrm{Ibb}$ & 79 & 13.2 \\
\hline Thamar & 24 & 4.0 \\
\hline \multicolumn{3}{|l|}{ Level of education: } \\
\hline Bachelor degree & 496 & 82.9 \\
\hline Masters degree & 102 & 17.1 \\
\hline \multicolumn{3}{|l|}{ Field of study: } \\
\hline Accounting & 345 & 57.7 \\
\hline Economic and political science & 68 & 11.4 \\
\hline Statistics & 75 & 12.5 \\
\hline Business administration & 110 & 18.4 \\
\hline \multicolumn{3}{|c|}{ Monthly income in Yemeni Riyal (YR) } \\
\hline Less than 20,000 & 29 & 4.8 \\
\hline $20,001-40,000$ & 30 & 5.0 \\
\hline $40,001-60,000$ & 77 & 12.9 \\
\hline $60,001-80,000$ & 139 & 23.2 \\
\hline $80,001-100,000$ & 234 & 39.1 \\
\hline $100,000-$ over & 89 & 14.9 \\
\hline \multicolumn{3}{|l|}{ Bank usage } \\
\hline Bank customer & 31 & 5.2 \\
\hline Non-bank customer & 567 & 94.8 \\
\hline
\end{tabular}




\subsection{Factor and reliability analysis}

Exploratory factor analysis (EFA) has been conducted on the behavioural intention (dependent variable) and on attitude and subjective norm. All the items have factor loading greater than 0.5 . In addition, the relative explanatory power (eigen-value) for the dimensions are $4.388,2.527$ and 2.325 respectively exceeding the recommended value of one and contributing $73.141,11.488$ and 11.624 respectively of the variance. Reliability test reveal that, behavioural intention has Cronbach alpha readings of 0.926, students' attitude has 0.822 and subjective norm has 0.911 . The Bartlett's test of sphericity for all the variables were significant.

\subsection{Correlations among attitude and subjective norm construct}

The result of the correlation test performed on the variables attitude and subjective norm as determinants of the behavioural intention, revealed that all aforementioned variables are correlated significantly and in the expected positive direction. Attitude toward bank usage $(r=.674, p<0.01)$, and subjective norm $(r=.0 .507, p<0.01)$. Table 2 depict the correlation result and also shows that students' attitude is the most highly correlated with the behavioural intention.

Table 2 Correlations among attitude construct

\begin{tabular}{lccc}
\hline Variables & DV & IV1 & IV2 \\
\hline DV- Behavioural intention & 1 & & \\
IV1- Students' attitude & $.674^{* *}$ & 1 & \\
IV2- Subjective norm & $.507^{* *}$ & & 1 \\
\hline
\end{tabular}

Notes: $* *$ Correlation is significant at the 0.01 level (2-tailed).

*Correlation is significant at the 0.05 level (2-tailed).

\subsection{Multicollinearity}

Multicollinearity appears when any individual predictor variable is highly correlated with another group of predictor variables (Mayer, 1999; Hair et al., 2006). Based on the multiple regression analysis as shown in Table 3, the results show that the tolerance value of attitude 0.975 was and for subjective norm was 0.722 and the variance inflation factor (VIF) value was in the range of 1.025 to 1.385 , Showing that the tolerance value is substantially greater than 0.10 and the VIF value is less than 10 , it can be concluded that multicollinearity among the variables is not a problem.

Table 3 Testing for multicollinearity on assessment of tolerance and VIF values

\begin{tabular}{lll}
\hline Variable & Tolerance & VIF \\
\hline Attitude toward bank usage & .975 & 1.025 \\
Social influence & .722 & 1.385 \\
\hline
\end{tabular}




\subsection{Multiple regression analysis}

The two constructs which are attitude and subjective norm explain $47.8 \%\left(R^{2}=.487\right)$ of the variance in behavioural intention. Standardised coefficient beta $(\beta)$ for attitude is significant and positive, showing that there is a positive linear relationship between attitude and behavioural intention to use bank systems, $\left(\beta=.563^{* *}, p<0.01\right)$ this is supported for the research's hypothesis (H1a), as shown in Table 4. Standardised coefficient beta $(\beta)$ for subjective norm is significant and positive, $\left(\beta=.211^{* *}, p<0.01\right)$ this is support for the research's hypothesis (H1b). Table 4, displays a summary of multiple regression results for both attitude and subjective norm as independent variables and the dependent variable of behavioural intention as follows.

Table 4 Summary of multiple regression results for attitude and subjective norm

\begin{tabular}{lc}
\hline Independent variables & Standardised coefficient beta $(\beta)$ \\
\hline Student attitude $\mathrm{H} 1$ & $0.563^{* *}$ \\
Subjective norm $\mathrm{H} 1$ & $0.211^{* *}$ \\
$R^{2}$ & 0.487 \\
Adjusted $R^{2}$ & 0.485 \\
Sig. F change & $0.000^{* * *}$ \\
F value & 282.253 \\
\hline
\end{tabular}

Note: ${ }^{*} p<0.05,{ }^{* *} p<0.01$

\section{Discussion}

\subsection{Attitude and behavioural intention}

The findings of this study shows that students' attitude has a positive and significant relationship with behavioural intention $\left(\beta=.563^{* *}, p<0.01\right)$ to use banking systems. This is the highest value of beta in the model, which implies that the variable attitude has the strongest influence on students' behavioural intention to use bank systems than subjective norm (Zegordi and Fakhredaei, 2011). The more favourable a student's attitude toward banking systems, the more likely the student is to use those services. In other words, students who have highly attitude are more likely to use the banking systems in the future. The result of this study was similar to other studies, which confirmed that the attitude is very important and has considerable influence on students' behavioural intention to use banking systems (Shih and Fang, 2006; Karjaluoto et al., 2002; Md-Nor et al., 2008; Rigopoulos and Askounis, 2007; Singh et al., 1995). This supports the study hypothesis (H1a). In addition, association between attitude and intention is essential in attitudinal research and has been confirmed in a huge variety of settings (Yang, 2012). In addition, the finding is consistent with the theory of reasoned action that says attitude is one of the main predictor of behavioural intention. Furthermore, the current study result is consistent with previous studies conducted in other less developed countries, which also establish a significance relationship between attitude and intention (Akour et al., 2010; Al Muala et al., 2009, 2012; Wahab, 2008; Zolait, 2010). Although attitude is the highest predictor of students' intention to use banking systems, also other powerful 
factors that researchers should examine in the future. Furthermore, this study focus on university students, which are the most educated people in the Yemeni society, which is reported $46 \%$ illiteracy (Library of Congress, 2008). Hence, the high level of attitude of respondents may reflect their high level of educational attainment. Education plays a vital role in human development, because it shows to people the opportunity to explore and benefit from their environment (Adeoye, 1999). Therefore, the highest level of attitude among students toward bank usage could be due to their level of knowledge and awareness of the benefit of the services that provided by banks.

\subsection{Subjective norm and behavioural intention}

The second research question deals with the relationship between subjective norm and behavioural intention. The study found subjective norm is a powerful predictive for behavioural intention and related positively and significantly with behavioural intention $\left(\beta=.211^{* *}, p<0.01\right)$ this found to be a stronger predictor on behavioural intention. Therefore, the research's hypothesis (H2) is supported. In addition, the study result is similar with many previous studies that supported the effects of subjective norms on the behavioural intentions (Amin and Chong, 2011; Bindin et al., 2009; Chen and Yang, 2007; Chiou, 1998; Ravi et al., 2007). In addition, students find support and encouragement from people who are important to them about using banking systems. This is a positive signal for them and a good step toward facilitate their financial needs through the banking system.

The finding also consistent with many previous studies in the banking field (Fauziah et al., 2008; Md-Nor et al., 2008; Zolait, 2010) as well as Agarwal et al. (2009) explored that subjective norms have a direct significant influence on consumers' intention to use banking systems. This could imply that social influence could have a certain amount of impact on students' intention to use the banking system in Yemen. The findings were in the expected direction, where the traditional culture of Yemeni confirmed the result. The Yemeni people modify their opinions with respect to others to whom they feel similar in accordance with psychological principles. Social pressure considered a critical issue in the Yemeni society, because individuals' referent or group that is important can affect the other feeling, attitude, and behaviour. This finding is congruent with the theory of reasoned action, which suggested the construct of subjective norms and described human intentions and behaviours as a result of the subjective assessment of events that occur in the environment.

\section{Conclusions}

The research framework that is derived from the TRA emphasises the importance of the two dimensions of the theory which are attitude and subjective norm in predicting the students' behavioural intention toward using banking service in Yemen. The results proved the association of attitude and subjective norm as independent variables and their positive influence on behavioural intention in less developing countries such as Yemeni. Initially, this study has a major contribution to understand the students behavioural toward using banking systems in the Yemeni environment. Understanding the magnitude of the influence of these variables have on university students' purchase intention, 
provide valuable facts that can help bankers, policy makers to design a marketing strategic considering these psychological factors (attitude and subjective norm).

This study adds to the literature by showing non-financial variables and identify certain useful psychological (attitude and subjective norm) factors that can help bankers, policy makers and research institutes to understand the consumers' need, want and expectation. As a result, they can meet the needs and wants of the university students and explore the benefits of using banks to increase bank access and spread the banking habit among university students in the Republic of Yemen. Moreover, the study provided essential information to monetary authorities in Yemen regarding students' behaviours and their attitudes toward bank systems. Such information might be helpful to monetary authorities in designing programmes that encourage students to facilitate their financial transaction through the banking system. Finally, the study contributes to the social psychology studies by using TRA in the Yemeni context, which is one of the very few studies that use TRA in Yemen and in the Arabic Peninsula in general. The research demonstrated that TRA is an effective theory that can be used to study the adoption of financial systems, particularly in examining behavioural intention of consumers in a similar context.

This study open a room to do further research in the future and study a range of factors that can be obstacles for the consumer to access the banking system. Therefore, this study is important and a good attempt to understand reasons behind of not using the banking system. This study focuses only on the attitude and subjective norm as the main factors that influence student to use the banking systems. Accordingly, we propose that future research should be directed toward empirically testing the direct influence of trust, where students' confidence and trust appear to be a weak point when it comes to the Yemeni banking system, and this influences the use of bank services (Al-Mushrqui, 2009). In an interview with Mrs. Al-Adhi, the Executive Director of the Central Bank of Yemen, she said that the Yemeni banking system in Yemen is not able to attract more than $4 \%$ of the total population. She attributed the reasons for low percentage of individuals who are not using banking system to the lack of banking culture of the population. It could be due to user's informational-based readiness on innovation acceptance (Zolait, et al., 2008). This is the reason why the majority of the population prefers to keep their money at home. Thus, research is needed to understand the influence of the Yemeni culture on behavioural intention to use banking systems.

The limitation that appeared in the current study owing to the result of the relationship between attitude and subjective norm on students' behavioural intention to use banking systems, which is a huge variation in the response rate between male and female respondents. While the response rate of male sample is $(78.6 \%)$ it is (21.4) for female sample. This difference is because females did not show cooperation in answering the questionnaire and some of them gave various excuses for not filling the questionnaire. This could reflect a higher rate of males' points of view. Moreover, by using the theory of reasoned action, the researchers may have excluded other factors from this study. Other constructs, such as economic factors such as poverty and unemployment, may affect the consumers' intentions to use banking system. Thus, these factors should be taken into consideration in future researches. 


\section{Acknowledgements}

The authors wish to express their gratitude to the anonymous reviewers who gave their time and efforts to review this research. The guidelines and comments received from the anonymous reviewers were very helpful to ensuring the quality of this published paper.

\section{References}

Abadi, H. and Gharibpoor, M. (2012) 'Consumers' attitudes and intensions towards reuse from e-services by using TPB model', Journal of Basic and Applied Scientific Research, Vol. 2, No. 4, pp.4352-4360.

Addison, B. and Chou, T. (2003) 'A theory of reasoned action model of accounting students' learning processes and learning strategies', Asian Review of Accounting, Vol. 11, No. 2, pp.53-72.

Adeoye, E.A. (1999) 'Predictors of stress in Nigerian executives', The Nigerian Journal of Guidance and Counseling, Vol. 6, Nos. 1/2, pp.44-66.

Agarwal, R., Animesh, A. and Prasad, K. (2009) 'Social interactions and the 'Digital Divide': explaining variations in internet use', Information Systems Research, Vol. 20, No. 2, pp.277-294.

Ajzen, I. and Fishbein, M. (1980) 'Understanding Attitudes and Predicting Social Behaviour', Prentice-Hall, Englewood Cliffs, NJ.

Ajzen, I., Brown, T.C. and Carvahal, F. (2004) 'Explaining the discrepancy between intentions and actions: the case of hypothetical bias in contingent valuation', Personality and Social Psychology Bulletin, Vol. 30, No. 9, pp.1108-1121.

Akour, N., Khassawneh, M., Khader, Y., Ababneh, A. and Haddad, A. (2010) 'Factors affecting intention to breastfeed among Syrian and Jordanian mothers: a comparative cross-sectional study', International Breastfeeding Journal, Vol. 5, No. 6, pp.1-8.

Al Muala, A., Al-Majali, M. and Al Ziadat, M. (2012) 'The usage of internet banking services among Jordanian consumers', Journal of Internet Banking and Commerce, Vol. 17, No. 1 pp.1-10.

Al Muala, A.M., Nik Mat, N.K. and Md Isa, F. (2009) Applications of Planned Behaviour Theory on International Tourists in Jordan: Structural Equation Modelling (SEM) Approach, pp.1-16.

Alajmi, B. (2010) 'The intention to share: psychological investigation of knowledge sharing behaviour in online communities', School of Communication and Information, pp.1-31.

Aleassa, H., Pearson, J. and McClurg, S. (2011) 'Investigating software piracy in Jordan: an extension of the theory of reasoned action', Journal of Business Ethics, Vol. 98, No. 4, pp.663-676.

Al-Maghrabi, T. and Dennis, C. (2012) 'The driving factors of continuance online shopping: gender differences in behaviour among students - the case of Saudi Arabia', Int. J. of Business Information Systems, Vol. 9, No. 4, pp.360-384.

Al-Mushrqui (2009) 'Doing business in Yemen: a country commercial guide for U.S. Companies', U.S. Department of State. [online] http://www.doingbusiness.org/data/ exploreeconomies/yemen/ (accessed 27 December 2012).

Amin, H. and Chong, R. (2011) 'Determinants for Ar-rahnu usage intentions: an empirical investigation', African Journal of Business Management, Vol. 5, No. 20, pp.8181-8191.

Bagozzi, R., Lee, K. and Loo, M. (2007) 'Decisions to donate bone marrow: the role of attitudes and subjective norms across cultures', Psychology \& Health, Vol. 16, No. 1, pp.29-56.

Bayraktar, N. and Wang, Y. (2008) 'Banking sector openness and economic growth', the Journal of Applied Economic Research, Vol. 2, No. 2, pp.145-175. 
Bindin, Z., Idris, K. and Shamsudin, F. (2009) 'Predicting compliance intention on Zakah on employment income in Malaysia: an application of reasoned action theory', Journal Penguruan, Vol. 28, pp.85-102.

CBY Annual Report (2010) Central Bank of Yemen Website [online] http://www.centralbank.gov.ye/ (accessed 20 June 2010).

Chen, I. and Yang, C. (2007) 'Using the theory of planned behaviour to understand in-service kindergarten teachers' behaviour to enrol in a graduate level academic program', Journal of College Teaching \& Learning, Vol. 4, No. 1, pp.11-13.

Chiou, J. (1998) 'The effects of attitude, subjective norm, and perceived behavioural control on consumers' purchase intentions: the moderating effects of product knowledge and attention to social comparison information', Vol. 9, No. 2, pp.298-308.

Doll, J. and Ajzen, I. (1992) 'Accessibility and stability of predictors in the theory of planned behaviour', Journal of Personality and Social Psychology, Vol. 63, No. 1, pp.754-765.

Fadare, S. (2010) 'Recent banking sector reforms and economic growth in Nigeria', Middle Eastern Finance and Economics, No. 8, pp.1-15 [online] http://www.eurojournals.com/MEFE_8_12.pdf (accessed 27 December 2012.

Fauziah, M.T., Ramayah and Dzuljastri, A. (2008) 'Factors influencing intention to use diminishing partnership home financing', International Journal of Islamic and Middle Eastern Finance and Management, Vol. 1, No. 3, pp.235-248.

Fishbein, M. and Ajzen, I. (1975) Belief, Attitude, Intention and Behaviour: An Introduction to Theory and Research, Addison-Wesley Publication Inc., USA.

George, J.F. (2002) 'Influences on the intent to make internet purchases', Internet Research, Vol. 12, No. 2, pp.165-80.

Gilaninia, S., Fattahi, A. and Mousavian, S. (2011) 'Behavioural factors tend to use the internet banking services case study: system (SABA) the Melli Bank, Iran, Ardabil', International Journal of Business Administration, Vol. 2, No. 3, pp.173-179.

Hair, J.F., Black, W.C., Babin, B.J., Anderson, R.E. and Tatham, R.L. (2006) Multivariate Data Analysis, 6th ed., Prentice Hall International, Upper Saddle River, New Jersey, USA.

Hernandez, J.M.C. and Mazzon, J.A. (2007) 'Adoption of internet banking: proposition and implementation of an integrated methodology approach', International Journal of Bank Marketing, Vol. 25, No. 2, pp.72-88.

Hostler, R., Yoon, V., Guo, Z., Guimaraes, T. and Forgionne, G. (2011) 'Assessing the impact of recommender agents on online consumer unplanned purchase behaviour', Information and Management, Vol. 48, No. 8, pp.336-343.

Hyllegard, K., Ogle, J. and Yan, R. (2009) 'The impact of advertising message strategy - fair labour v. sexual appeal - upon Gen Y consumers' intent to patronize an apparel retailer', Journal of Fashion Marketing and Management, Vol. 13, No. 1, pp.109-127.

Karjaluoto, H., Mattila, M. and Pento, T. (2002) 'Factors underlying attitude formation towards online banking in Finland', International Journal of Bank Marketing, Vol. 20, No. 6, pp.261-272.

Khaledi, S., Saiedi, M., Nazari, M., Gilaninia, S. and Mousavian, S. (2012) 'Factors that influence customers to use electronic services in the customer's bank Parisian bank (West branches of the case study)', Interdisciplinary Journal of Contemporary Research in Business, Vol. 3, No. 9, pp.822-832.

Kim, Y. (2008) An Empirical Examination of Consumers' Innovation Adoption: The Role of Innovativeness, Fashion Orientation, and Utilitarian and Hedonic Consumers' Attitudes. Master Thesis, University of North Carolina.

King, R. and Levine, R. (1992) Financial Indicators, and Growth in a Cross Section of Countries, World Bank W.P. 819.

Krejcie, R.V. and Morgan, D.W. (1970) 'Determining sample size for research', Educational and Psychological Measurements, Vol. 30, No. 3, pp.607-610. 
Lee, M., Shi, N., Cheung, C., Lim, K. and Sia, C. (2011) 'Consumer's decision to shop online: the moderating role of positive', Information and Management, Vol. 48, No. 6, pp.185-191.

Leonard, L.K. (2012) 'Attitude influencers in c2c e-commerce: buying and selling', The Journal of Computer Information Systems, Vol. 52, No. 3 pp.11-17.

Library of Congress (2008) Country Profile: Yemen, Federal Research Division.

Lin, H., Wu, C. and Yang, J. (2011) 'A productivity review study on theory of reasoned action literature using bibliometric methodology', International Conference on Management and Service Science, IACSIT Press, Singapore.

Lymperopoulos, C. and Chaniotakis, I. (2005) 'Factors affecting acceptance of the internet as a marketing-intelligence tool among employees of Greek bank branches', The International Journal of Bank Marketing, Vol. 23, No. 6, pp.484-505.

Mayer, K.J. (1999) Exploring the Role of Service Process and Its Effect on Guest Encounter Satisfaction, Doctoral dissertation, Graduate College, University of Nevada, Las Vegas, UMI Dissertation Services, Ann Arbor, MI.

McKemey, K. and Rehman, T. (2003) 'The theory of reasoned action and its application to understand the relationship between attitudes and behaviours: an introduction and a review', [online] http://www.nrsp.org/database/documents/1975.pdf (accessed January 2009).

McLeod, A. and Pippin, S. (2012) 'Toward multi-dimensional trust: exploring antecedents to trust in a complex domain', Int. J. of Business Information Systems, Vol. 9, No. 2 pp.222-238.

Md-Nor, K., Abu Shanab, E. and Pearson, J. (2008) 'Internet banking acceptance in Malaysia based on the theory of reasoned action', Journal of Information Systems and Technology Management, Vol. 5, No. 1, pp.3-14.

Page, C. and Luding, Y. (2003) 'Bank managers' direct marketing dilemmas - customers' attitudes and purchase intention', The International Journal of Bank Marketing, Vol. 21, No. 3, pp.147-163.

Prendergast, G., Tsang, A. and Yu Lo, C. (2008) 'Antecedents of the intention to seek samples', European Journal of Marketing, Vol. 42, Nos. 11/12, pp.1162-1169.

Ravi, V., Carr, M. and Sagar, N.V. (2007) 'Profiling of internet banking users in India using intelligent techniques', Journal of Services Research, Vol. 7, No. 1, pp.61-73.

Rigopoulos, G. and Askounis, D. (2007) 'A TAM framework to evaluate users' perception towards online electronic payments', Journal of Internet Banking and Commerce, Vol. 12, No.3, pp.1-6.

Rosly, S.A. (2005) Critical Issues on Islamic Banking and Financial Markets: Islamic Economics, Banking and Finance, Investments, Takaful and Financial Planning, Dinamas Publishing, Kuala Lumpur.

Rugimbana, R. (2007) 'Generation Y: how cultural values can be used to predict their choice of electronic financial services', Journal of Financial Services Marketing, Vol. 11, No. 4, pp.301-313.

Sadeghi, T. and Farokhian, S. (2011) 'The role of behavioural adoption theories in online banking services', Middle-East Journal of Scientific Research, Vol. 7, No. 3, pp.374-380.

Sekaran, U. (2003) Research methods for Business: A Skill-Building Approach, 4th ed., John Wiley \& Sons, Inc., New York, NY.

Shih, Y. and Fang, K. (2006) 'Effects of network quality attributes on customer adoption intentions of internet banking', Total Quality Management, Vol. 17, No. 1, pp.61-77.

Shin, D. (2009) 'Determinants of customer acceptance of multi-service network: an implication for IP-based technologies', Information and Management, Vol. 46, No. 1, pp.16-22.

Singh, K., Leong, S., Tan, C. and Wong, K. (1995) 'A theory of reasoned action perspective of voting behaviour: model and empirical test', Psychology and Marketing, Vol. 12, No. 1, pp.37-52. 
Southey, G. (2011) 'The theories of reasoned action and planned behaviour applied to business decisions: a selective annotated bibliography', Journal of New Business Ideas \& Trends, Vol. 9, No. 1, pp.43-50.

Swidi, A. and Mahmood, R. (2011) 'Yemeni banking system: critical issues and future recommended strategies', European Journal of Social Sciences, Vol. 4, No. 20, pp.637-655.

Tan, G., Sim, J., Ooi, K. and Phusavat, K. (2012) 'Determinants of mobile learning adoption: an empirical analysis', The Journal of Computer Information Systems, Vol. 52, No. 3 pp.82-91.

Tarkiainen, A. and Sundqvist, S. (2005) 'Subjective norms, attitudes and intentions of Finnish consumers in buying organic food', British Food Journal, Vol. 107, No. 11, pp.808-822.

Tsai, M., Chin, C. and Chen, C. (2010) 'The effect of trust belief and salesperson's expertise on consumer's intention to purchase nutraceuticals: applying the theory of reasoned action', Social Behaviour and Personality, Vol. 38, No. 2, pp.273-288.

Wahab, A. (2008) 'Modelling students' intention to adopt e-learning: a case from Egypt', The Electronic Journal on Information Systems in Developing Countries, Vol. 34, No. 1, pp.1-13.

Wang, W. and Butler, J.E. (2006) 'System deep usage in post-acceptance stage: a literature review and a new research framework', Int. J. of Business Information Systems, Vol. 1, No. 4, pp.439-462.

Weber, W., Martin, M. and Corrigan, M. (2007) 'Real donors, real consent: testing the theory of reasoned action on organ donor consent', Journal of Applied Social Psychology, Vol. 37, No. 10, pp.2435-2450.

World Bank Group (2010) Doing Business in Yemen World Bank [online] http://www.doingbusiness.org/data/exploreeconomies/yemen/ (accessed 20 June 2010).

Yang, T. (2012) 'The decision behaviour of facebook users', The Journal of Computer Information Systems, Vol. 52, No. 3, pp.50-59.

Yemen Times (2008) Yemen's Economic Freedom: Going Nowhere [online] http://www.yementimes.com (accessed 24 January 2008 to 27 January 2008).

Yousafzai, S., Foxall, G. and Pallister, J. (2010) 'Explaining internet banking behaviour: theory of reasoned action, theory of planned behaviour, or technology acceptance model', Journal of Applied Social Psychology, Vol. 40, No. 5, pp.1172-1202.

Zegordi, S.H. and Fakhredaei, N. (2011) 'The factors affecting adoption of CRM at organisational level in Iran's shipping industry', Int. J. of Business Information Systems, Vol. 8, No. 2, pp.165-191.

Zolait, A. (2010) 'An examination of the factors influencing Yemeni bank users' behavioural intention to use internet banking services', Journal of Financial Services Marketing, Vol. 15, No. 1, pp.76-94.

Zolait, A., Mattila, M. and Sulaiman, A. (2008) 'The effect of user's informational-based readiness on innovation acceptance', International Journal of Bank Marketing, Vol. 27, No. 1, pp.76-100. 